ISSN 2587-8123 (Print) ISSN 2658-5995 (Online)

МИНИСТЕРСТВО НАУКИ И ВЫСШЕГО ОБРАЗОВАНИЯ РОССИЙСКОЙ ФЕДЕРАЦИИ ВОЛГОГРАДСКИЙ ГОСУДАРСТВЕННЫЙ УНИВЕРСИТЕТ

НИЖНЕВОЛЖСКИЙ АРХЕОЛОГИЧЕСКИЙ ВЕСТНИК 2021 Tом 20. № 2

MINISTRY OF SCIENCE AND HIGHER EDUCATION OF THE RUSSIAN FEDERATION VOLGOGRAD STATE UNIVERSITY

THE LOWER VOLGA ARCHAEOLOGICAL BULLETIN 2021 Volume 20. No. 2

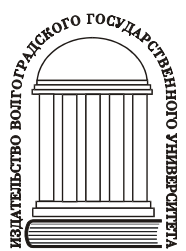




\section{СОДЕРЖАНИЕ}

Конец прекрасной эпохи (Редакциионная коллегия) .... 5

\section{СТАТЬИ}

Файзуллин И.А., Купцова Л.В., Мухаметдинов В.И. Гончарное производство срубной культуры Предуралья по материалам курганного могильника I у села Твердилово

Балабанова М.А., Клепиков В.М., Перерва Е.В. Погребальный обряд и морфология погребенного из кургана могильника Тау (Западный Казахстан) .... 24

Монахов С.Ю. Типология и хронология аканфских амфор [На англ. яз.] 43

Абрамова А.Н. Население Прикубанья раннего железного века по данным краниофенетики (предварительные данные) .66

Малашев В.Ю., Маслов В.Е. Курганы-кладбища центральных и восточных районов Северного Кавказа III в. до н.э. - начала (первой половины) II в. н.э. (памятники типа Чегем-Манаскент)

Ковалева К.С. Производственные

бронзолитейные комплексы

городов Золотой Орды: поиск аналогий

Дрёмов И.И., Круглов Е.В. Железные конусы в погребениях Улуса Джучи:

аспекты этнокультурной принадлежности 149

Гаглойты Р.Х., Кочкаров У.Ю., Мамаев Р.Х., Нарожный В.Е., Нарожный Е.И. Наконечники копий келийского каменноящечного могильника (Горная Ингушетия)

\section{ПУБЛИКАЦИИ}

Кривочеев М.В., Моисеев В.И.

Погребения раннесарматского времени

с территории Чеченской Республики

Иванов С.С. Редкая поясная бляха

в зооморфном стиле с Внутреннего Тянь-Шаня..... 196

Николаев С.Ю. Три сарматских кинжала

с подножия горы Торатау 204

\section{НАУЧНАЯ ЖИЗНЬ}

Итоги VI Нижневолжской Международной археологической научной конференции «Волго-Уральский регион от древности до Средневековья» (Оргкомитет конферениии) 214

\section{CONTENTS}

The End of a Great Era (Editorial Staff) 5

\section{ARTICLES}

Fayzullin I.A., Kuptsova L.V., Mukhametdinov V.I. The Ceramics Production of the Cis-Ural Srubnaya Culture: A Case Study of the Kurgan Cemetery I Near Tverdilovo Village ..... 8

Balabanova M.A., Klepikov V.M., Pererva E.V. Funeral Rite and Morphology of a Buried Man from Kurgan of Tau Cemetery (Western Kazakhstan) .... 24 Monakhov S.Yu. Typology and Chronology of Akanthian Amphorae

Abramova A.N. Craniophenetic Features

of Cis-Kuban Population of the Early Iron Age (Preliminary Data)

Malashev V.Yu., Maslov V.E. Kurgan-Cemeteries of Central and Eastern Regions of North Caucasus $3^{\text {rd }}$ Century BC - Early $2^{\text {nd }}$ Century AD

(Monuments Chegem-Manaskent Type)

Kovaleva K.S. Manufacturing Complexes for the Non-Ferrous Metals Processing of the Golden Horde Cities: Search for Analogies

Dremov I.I., Kruglov E.V. Iron Cones

in the Burials of Ulus Jochi:

Aspects of Ethnocultural Identification

Gagloiti R.H., Kochkarov U.U., Mamaev R.Kh., Narozhnyi V.E., Narozhnyi E.I. Spearheads of the Keliysky Stone Box Burial Ground (Ingushetia Highlands)

\section{PUBLICATIONS}

Krivosheev M.V., Moiseev V.I.

Early Sarmatian Burials

from the Chechen Republic Territory

Ivanov S.S. A Rare Belt Plaque in Zoomorphic Style from the Inner Tien Shan.... 196

Nikolaev S.Yu. Three Sarmatian Daggers

from the Foot of Toratau Mount

\section{SCIENTIFIC LIFE}

Proceedings of the $6^{\text {th }}$ Lower Volga International Scientific Conference on Archaeology

"The Volga-Ural Region -

from Antiquity to the Middle Ages"

(Organizing Committee of the Conference) 214 


\title{
MANUFACTURING COMPLEXES FOR THE NON-FERROUS METALS PROCESSING OF THE GOLDEN HORDE CITIES: SEARCH FOR ANALOGIES ${ }^{1}$
}

\author{
Kseniya S. Kovaleva \\ Institute of Archaeology of the Russian Academy of Sciences, Moscow, Russian Federation; \\ Volgograd State University, Volgograd, Russian Federation
}

\begin{abstract}
The article is devoted to the Golden Horde complexes associated with the processing of nonferrous metals and the organization of handicraft production. Historiography has repeatedly voiced the significant role of the masters of the conquered territories in the formation of the metalworking production of the Golden Horde. In the article the characteristic features of the Golden Horde craft complexes are considered in comparison with similar complexes of Kievan Rus cities, as well as with some traditions of the organization of Central Asian craft. Data from workshops of Tsarevskoe, Uvekskoe, Bolgarskoe settlements, Staryy Orhey were brought in. The complexes are considered in terms of such parameters as location in the city planning system, type of structure, presence of smelting furnaces and hydraulic structures, set of production, range of products and coexistence with other industries. It is noted that in the cities of the Golden Horde there are various forms of organization of metalworking crafts, small workshops in craft districts and complex workshops functioning within household plots. The workshops location is not clearly defined; in general, they do not form specialized areas. The structures in which the workshops operate have no design features and may not contain heat engineering structures. Workshops for the processing of non-ferrous metals most often function in conjunction with bone carving and pottery production, less often in a composition with leather, glass making, and gemstone processing. This is significantly different from the situation in Kievan Rus cities, where the processing of non-ferrous metals is most often combined in various forms with the processing of ferrous metals. The handicraft complexes of the Golden Horde cities demonstrate a wide variety of forms, and most of them find their analogies in the materials of ancient Russian cities, therefore, it is difficult to single out specific features indicating possible genetic connections.
\end{abstract}

Key words: Golden Horde, Kievan Rus, non-ferrous metal processing, manufacturing complex, craft.

Citation. Kovaleva K.S., 2021. Proizvodstvennye bronzoliteynye kompleksy gorodov Zolotoy Ordy: poisk analogiy [Manufacturing Complexes for the Non-Ferrous Metals Processing of the Golden Horde Cities: Search for Analogies]. Nizhnevolzhskiy Arkheologicheskiy Vestnik [The Lower Volga Archaeological Bulletin], vol. 20, no. 2, pp. 133-148. DOI: https://doi.org/10.15688/nav.jvolsu.2021.2.6

УДК 902(653):903.46

Дата поступления статьи: 17.09.2021

ББК 63.444(235.54)

Дата принятия статьи: 25.11.2021

\section{ПРОИЗВОДСТВЕННЫЕ БРОНЗОЛИТЕЙНЫЕ КОМПЛЕКСЫ ГОРОДОВ ЗОЛОТОЙ ОРДЫ: ПОИСК АНАЛОГИЙ ${ }^{1}$}

\author{
Ксения Сергеевна Ковалева \\ Институт археологии РАН, г. Москва, Российская Федерация; \\ Волгоградский государственный университет, г. Волгоград, Российская Федерация
}

Аннотация. Статья посвящена золотоордынским комплексам, связанным с обработкой цветных металлов и вопросами организации ремесленного производства. В историографии неоднократно озвучивалась значительная роль мастеров завоеванных территорий в становлении металлообрабатывающего производства Золотой Орды. В рамках статьи характерные черты золотоордынских ремесленных комплексов рассмотрены в сравнении с аналогичными комплексами древнерусских городов, а также с некоторыми традициями организации среднеазиатского ремесла. Привлечены данные мастерских по обработке цветных металлов Царевского, Увекского, Болгарского городищ, Старого Орхея. Комплексы рассмотрены по таким парамет- 
рам, как расположение в системе планировки города, тип сооружения, наличие плавильных печей и гидротехнических сооружений, направление производства, ассортимент продукции, сосуществование с другими производствами. Отмечено, что в городах Золотой Орды функционируют разные формы организации металлообрабатывающего ремесла, небольшие мастерские в ремесленных кварталах и комплексные мастерские, функционирующие в рамках приусадебных хозяйств. Расположение мастерских не имеет четко выраженной локализации, в основном они не формируют специализированные районы. Сооружения, в которых функционируют мастерские, не имеют конструктивных особенностей, могут не содержать теплотехнические сооружения. Мастерские по обработке цветных металлов чаще всего функционируют в комплексе с косторезным и гончарным производствами, реже - в составе с кожевенным, стеклоделательным и обработкой камней. Это значительно отличается от ситуации в древнерусских городах, где обработка цветных металлов чаще всего в разных формах сочетается с обработкой черных металлов. Ремесленные комплексы золотоордынских городов демонстрируют большое разнообразие форм, и большинство из них находит свои аналогии в материалах древнерусских городов, поэтому выделить специфические черты, указывающие на возможные генетические связи, затруднительно.

Ключевые слова: Золотая Орда, Древняя Русь, обработка цветных металлов, производственный комплекс, ремесло.

Цитирование. Ковалева К. С., 2021. Производственные бронзолитейные комплексы городов Золотой Орды: поиск аналогий // Нижневолжский археологический вестник. Т. 20, № 2. С. 133-148. DOI: https://doi.org/10.15688/nav.jvolsu.2021.2.6

Город в эпоху Средневековья представляет собой центр мелкого товарного производства, выступая одновременно и производителем, и потребителем ремесленных изделий [Зиняков, 2013, с. 232]. В золотоордынских городах ремесленные кварталы занимают значительную, нередко центральную, часть города [Егоров, 1985, с. 114]. О немалых масштабах производства может свидетельствовать тот факт, что продукция мастеров по металлу нижневолжских городов поступала в другие регионы Золотой Орды, на Среднюю Волгу в Болгар [Крамаровский, Полубояринова, 1982, с. 100] и юго-западный Крым [Масюта, Лесная, 2020, с. 240-242], в древнерусских городах существовала определенная «мода» на золотоордынские вещи и их местные подражания [Горелик, 2008]. Определенно, города обеспечивали изделиями из цветных металлов собственную кочевую округу [Король, Наумова, 2017, с. 55]. Однако, как справедливо отмечено С.И. Валиулиной, ремесленные традиции Золотой Орды не имеют периода становления, а появляются в результате прямого заимствования уже готовых технологических практик [Валиулина, 2020, c. 41]. Основные точки зрения касательно истоков металлообрабатывающего производства были высказаны еще в 30-50-е гг. ХХ века. А.Ю. Якубовский видел их на Кавказе - в области Дагестана или Азербайджана [Якубовский, 1931, с. 27], а также отмечал вклад русских мастеров [Греков, Якубовский, 1941, c. 153]. Об огромной роли русских, хорезмских и закавказских мастеров в формировании культуры золотоордынских городов писал в своей работе о ремесле Древней Руси Б.А. Рыбаков [Рыбаков, 1948, с. 531]. М.Г. Сафаргалиевым высказывалось достаточно радикальное мнение, что нельзя говорить даже о заимствовании традиций, большинство изделий из металла изготавливались непосредственно русскими мастерами [Caфаргалиев, 1960, с. 76-78].

Вопросы об организации ремесленного производства как одного из составляющих культуры в золотоордынских городах, уровне развития и корнях традиций также стали подниматься еще до начала активных археологических работ и появления массового вещественного материала. Одним из первых к нему обратился А.Ю. Якубовский. Основываясь на результатах полевых исследований на Царевском городище А.В. Терещенко в 40-х гг. XIX в., он предположил наличие в городе крупных железо- и медеплавильных заводов, а также огромного количества мастерских по выделке изделий из железа и меди. По его мнению, металлургическая промышленность, наряду с керамической, занимала в этом столичном городе главное место и представляла собой производства мануфактурного типа кархане («корхана», «корхара»), под которыми понимал большие мастерские с разделе- 
нием труда, принадлежащие ханскому двору, крупным купцам или феодалам [Греков, Якубовский, 1941, с. 146]. При этом особая роль в организации ремесленного производства отводилась торговым компаниям - именно они держали крупные ремесленные заведения [Якубовский, 1931, с. 16-19].

Г.А. Федоров-Давыдов обобщил результаты многолетних исследований золотоордынских городов Поволжской археологической экспедицией и пришел к выводу о наличии разных видов организации ремесла. По его мнению, существовали индивидуальные мастерские с узкой специализацией и небольшим объемом работ, усадебные мастерские, где разные по профессии ремесленники с узкой специализацией работали на хозяина, и, наконец, мастерские, которые достигли больших размеров, объединяли в себе несколько десятков ремесленников и выпускали более разнообразную продукцию, собственно кархане. Последнюю форму он выделял только на керамическом производстве, приводя в пример гончарную мастерскую на Селитренном городище [Федоров-Давыдов, 1997, с. 100-101].

Мастерские кархане известны по письменным источникам, об их существовании в хулагуидском Иране сообщает Рашид ад-Дин [2011, с. 35, 336, 352]. Кархане сравнивают с известными повсеместно на Ближнем Востоке в период арабского халифата казенными мастерскими - тиразами. Нередко тиразы были собственностью отдельных лиц [Кикнадзе, 1962, с. 48-49]. И хотя высказывалось мнение о дальневосточном или уйгуро-монгольском происхождении кархане [Беленицкий, 1948, с. 123], в основных аргументах против такой версии указывалось, что большие казенные мастерские существовали в городах Ближнего Востока в период халифата и продолжали действовать непосредственно перед монгольским нашествием, о чем свидетельствуют письменные источники, в то время как в монгольских и китайских источниках не упоминается о существовании там подобных государственных мастерских [Кикнадзе, 1962, c. 50]. Несмотря на значительный урон, нанесенный городской экономике монголами во время нашествия, ремесленное производство необходимо было быстро восстанавливать, так как завоеватели нуждались в большом ко- личестве ремесленной продукции. Чтобы както удовлетворить потребности военной знати и войска, они начали создавать большие мастерские, так называемые кархане, принадлежавшие государству или монгольским ханам и выполнявшие государственные заказы. Таким образом, монголы не принесли в Иран новых форм организации ремесленного труда, но воспользовались существовавшей формой [Кикнадзе, 1962, с. 50].

Есть свидетельства, что на раннем этапе существования золотоордынского государства ханы Улуса Джучи пользовались возможностями кархане на территории Ирана. Так, например, основным источником поступления оружия в Орду до конфликта с хулагуидами были кархане Северо-Западного Ирана [Кулешов, 2014, с. 210]. Арабский историк ОлАмари сообщает, что в Тебризе были выстроены мастерские карханат по изготовлению ткани для золотоордынского хана Берке [Кикнадзе, 1962, с. 50]. До становления развитой городской культуры в начале XIV в., ремесленное производство на территории Нижнего Поволжья оставалось кустарным и не могло обеспечить молодое государство необходимой продукцией.

В рамках данной статьи сделана попытка рассмотреть золотоордынские городские производственные комплексы, специализирующиеся на обработке цветных металлов, в сравнении с мастерскими древнерусских городов домонгольского и монгольского периодов, а также некоторыми традициями организации ремесла Средней Азии, чтобы выявить возможные связи.

Производственным комплексом, или мастерской, принято считать совокупность единовременных и территориально близко расположенных сооружений, характер находок в которых позволяет судить о наличии производственной деятельности [Зайцева, Сарачева, 2011, с. 35]. Определение ремесленных комплексов как бронзолитейных происходит по наличию таких индикаторов производства, как отработанные тигли, обрезки металла, специализированные инструменты (миниатюрные наковаленки, молоточки, штампы), заготовки, выплески и капли металла, остатки сооружений, связанные с высокотемпературными процессами. 
Как показали экспериментальные исследования, бронзолитейное производство может быть весьма неуловимым, остатки теплотехнических сооружений часто принимаются в лучшем случае за очаг [Саврасов, 2013, с. 125-126]. Экономное отношение мастера к сырью приводит к тому, что на место плавки могут указывать только капли металла диаметром всего в несколько миллиметров [Söderberg, 2002, S. 261]. Многие инструменты могут быть нераспознанными из-за коррозии металла, и даже тигли могли перерабатываться ремесленниками в шамот [Söderberg, 2002 , S. 259]. Некоторые из инструментов волочильные доски, наковальни или литейные формы - могли быть изготовлены из дерева, а соответственно, не сохраниться до момента исследования.

По совокупности признаков на территории Нижнего Поволжья исследователями выявлено несколько золотоордынских комплексов, определенных как мастерские по обработке цветных металлов. Три из них были открыты в результате многолетних работ Поволжской археологической экспедиции на территории Царевского городища [Федоров-Давыдов и др., 1974; Гусева, 1974; Байрамова, Зеленеев, 2000, с. 19-21; Зеленеев, Курочкина, 2009, с. 73-85]. Сведения о металлообрабатывающем производстве содержатся и в материалах, описывающих исследование городища в середине XIX - начале XX в. [Терещенко, 1850 , с. 382,384 ; Баллод, 1923, с. 22]. На Увекском городище известен комплекс, определенный автором раскопок как «жилище мастера», который с некоторыми оговорками, но также рассматривается как мастерская [Кубанкин, 2010; 2013]. Работами последних лет на городище выявлен еще один комплекс производств, включающий обработку цветных металлов [Яворская, 2020, с. 223]. 3а пределами Нижневолжского региона открыты мастерские на территории золотоордынского Болгара [Полякова, 1996, с. 157-158; Кокорина, 2005; Аксенова, Полубояринова, 2005; Бадеев, Коваль, 2018] и Старого Орхея [Бырня, 1974]. Многочисленные следы производств по обработке цветных металлов, позволяющих говорить о специализированных районах металлообработки, но без выделения отдельных комплексов, известны в Азаке
[Масловский, 2015, с. 396-398]. Эти данные также привлечены для сравнения.

Расположение комплексов в системе планировки города. Мастерские сильно разнятся по территориальному положению. Две ювелирные мастерские Царевского городища располагались в восточном пригороде, на территории аристократических усадеб с комплексами производств [Гусева, 1974, c. 125]. Еще одна бронзолитейная мастерская открыта в центральной, торгово-ремесленной части города с квартальной застройкой [Зеленеев, Курочкина, 2009, с. 73]. А.В. Терещенко, исследовавший городище в 1843-1851 гг., писал в своих дневниках о находках в центральной части города «плавильных чашечек с остатками в них металла», весов, глиняных и каменных литейных форм [Терещенко, 1850 , с. 382, 384]. Раскопками Ф.В. Баллода в 1922 г. зафиксированы следы работы с цветным металлом в виде тиглей, большого количества мелких слитков меди и готовых изделий в северной, вероятно ремесленной, части городища [Баллод, 1923, с. 22; Глухов, 2015, с. 52].

На Увекском городище комплекс, связанный с литьем серебра, выявлен на северо-западной окраине, где предположительно располагался район ремесленных производств по обработке черных и цветных металлов [Кубанкин, 2013, с. 179, 185]. Следы комплекса производств середины XIV в., где косторезное и кожевенное ремесла соседствуют с обработкой цветных металлов [Яворская, 2020, с. 223], открыты в результате работ 2019 г. в центральной части городища.

На территории Болгарского городища металлургическое и металлообрабатывающие (в том числе ювелирное) производства зафиксированы в центральной, торгово-ремесленной части города [Кокорина, 2005; Бадеев, Коваль, 2018]. Также металлообрабатывающие комплексы открыты на территории ремесленного квартала в юго-западной части городища [Полякова, 1996, с. 158; Аксенова, Полубояринова, 2005]. Здесь, в районе Голландского (Галанского) озера, функционировало крупное гончарное производство, и, по мнению Д.Ю. Бадеева, местные мастерские по обработке черного и цветного металла были ориентированы на его обслуживание [Бадеев, 2018, с. 83]. В Азаке следы обработки цветного металла 
рассеяны по всей центральной части городища [Масловский, 2015, с. 397]. Мастерская из золотоордынского Старого Орхея (Молдавия) располагалась также в центральной части города, примыкая одной стеной к караван-сараю, и была окружена другими производственными комплексами, образующими ремесленный квартал [Абызова и др., 1981, с. 30].

Примеры размещения древнерусских мастерских также не демонстрируют какогото четкого положения в структуре городской застройки. Производственные комплексы могли располагаться в центральной части города [Колчин, 1985, с. 261], в детинце, занимая его периферийные части [Зайцева, 2010, с. 202; Зайцева, Сарачева, 2011, с. 53], могли входить в состав городских усадеб [Колчин, 1985, с. 261; Сингх, 2011, с. 233-235; Троицкий, 2019, с. 216], формировали окраинные ремесленные кварталы [Кренке и др., 2016, с. 22; Троицкий, 2019, c. 217] или занимали удаленные друг от друга участки поселений [Мурашева и др., 2007, c. 31]. В то же время в некоторых городах, например в Пскове, зафиксирована тенденция перемещения мастерских от центра в ремесленные посады по мере увеличения городской территории [Королева, 2003, с. 220].

Тип сооружения. Мастерские золотоордынских городов относятся к разным типам сооружений и имеют разную планировку. Одна из усадебных ювелирных мастерских Царевского городища представляла собой обмазанную глиной деревянную с сырцовым цоколем пристройку к жилому дому. Другая мастерская располагалась в землянке со стенами из сырцовых кирпичей и глиняным полом. Кроме того, следы работы ювелира зафиксированы и в наземном жилом доме, входящем в усадебный комплекс [Гусева, 1974, c. 129, 132]. Мастерская медника, открытая также на Царевском городище, располагалась в отдельном сооружении, выполненном из сырцовых кирпичей с известковой обмазкой, сначала с известковым, а позднее - глиняным полом [Зеленеев, Курочкина, 2009, с. 75-76]. Мастерская Увекского городища представляла собой частично заглубленную в землю постройку со стенами из двух собранных из досок щитов и засыпкой песком между ними. Само сооружение являлось жилым, производственное пространство располагалось в юж- ной его половине. Ссылаясь на исследования Г.А. Федорова-Давыдова и В.Л. Егорова, автор раскопок Д.А. Кубанкин отметил, что такие постройки являлись простым и распространенным жилищем ремесленников в Золотой Орде [Кубанкин, 2013, с. 182]. Одна из ювелирных мастерских торгово-ремесленного квартала Болгара располагалась в многокомнатном сооружении, состоящем из наземного и полуземляночного помещения со стенами из глиняной забутовки и бревен [Кокорина, 2005, c. 110-111]. В юго-западном ремесленном квартале производственные сооружения представлены землянками с деревянными стенами или подполом наземного дома [Аксенова, Полубояринова, 2005, с. 135-143]. Ювелирная мастерская Старого Орхея располагалась в одном из отсеков трехкамерного сооружения, состоящего из жилой и производственной частей. Стены последнего, вероятно, были возведены из камней, кирпичей и глиняной обмазки, а пол сооружен из мелких камней и щебня, залитых известкой [Бырня, 1974, с. 231-232].

Таким образом, все открытые постройки являлись наземными, а землянки зафиксированы в основном на территории крупных усадеб, что соотносится с данными по ремесленным мастерским разных специализаций в целом по Золотой Орде [Егоров, 1970, c. 191]. Вероятно, эти мастерские могли работать на обслуживание населения ближайших кварталов. Производственные комплексы, расположенные в землянках юго-западной ремесленной части Болгара, Н.Д. Аксенова и М.Д. Полубояринова связывают с городской беднотой и зависимым населением, в том числе русским [Аксенова, Полубояринова, 2005, с. 142].

Другая ситуация отмечается в древнерусских комплексах. Землянки в качестве производственного помещения встречаются достаточно часто, например на территории Спас-Городка [Зайцева, 2010, с. 199], Старой Рязани [Троицкий, 2019, с. 216] или даже Гнездова, где отмечены связи со скандинавскими традициями использования углубленных построек без отопительных сооружений в качестве ремесленно-хозяйственных [Мурашева и др., 2007 , с. 37-38]. Помимо землянок, в качестве производственных помещений зафиксированы пристройки к жилому дому в Киеве, нежилые 
столбовые конструкции и жилые дома в Новгороде [Колчин, 1985, с. 261; Сингх, 2011, c. 234-235]. Сочетание функций жилища и мастерской в целом характерно для большинства мастерских древнерусских городов [Ениосова и др., 2011, с. 139; Королева, 2003, с. 222; Рындина, 1963, с. 226]. Отмечено, что постройки, связанные с ювелирным производством, не имеют конструктивных особенностей, по сравнению с теми, которые к производству отношения не имеют [Королева, 2003, с. 220].

Плавильные печи, сооруженные из обожженного кирпича, были зафиксированы в мастерской Царевского городища [Гусева, 1974 , с. 129], из обожженной глины - на Болгарском городище [Кокорина, 2005, с. 109; Аксенова, Полубояринова, 2005, с. 135-137, 139; Бадеев, Коваль, 2018, с. 277], из глины с известковой обмазкой и кирпичным дном - в мастерской медника Царевского городища [Зеленеев, Курочкина, 2009, с. 78]. В располагавшейся в землянке ювелирной мастерской Царевского городища печь отсутствует, однако ее функцию, а именно использование для плавки металла, с большой долей вероятности исполняла вырытая рядом яма, в которой зафиксированы следы литья (прослойка, насыщенная каплями металла) [Гусева, 1974, с. 129]. В мастерской Увека теплотехнических сооружений и следов производства обнаружено не было, несмотря на предполагаемую по наличию тиглей литейную специализацию. В Старом Орхее не были зафиксированы ни печи, ни следы литья, но возможно, что мастерская была направлена на холодную кузнечную обработку цветных металлов, что подтверждается и составом находок - инструментария и отходов производства (обрезки).

Отсутствие специализированных помещений и печей-горнов в связанных с обработкой цветных металлов производственных комплексах нередко отмечается для древнерусских городов. Э.В. Королева, исследовавшая обработку цветных металлов в средневековом Пскове, отметила, что дворы ювелиров и медников часто соседствуют с железообрабатывающими комплексами, где и могли происходить все процессы, связанные с высокими температурами [Королева, 2003, с. 223].

Рядом с мастерскими Царевского и Увекского городищ зафиксированы связанные с ними искусственные водоемы, необходимость которых очевидна для производств, связанных с высокими температурами. Расположение производственных комплексов вдоль водоема отмечено в Смоленске [Кренке и др., 2016, с. 22]. В кузнечно-ювелирной мастерской Гнездова небольшая яма, использовавшаяся предположительно в качестве искусственного водоема для закалки железных изделий, обнаружена непосредственно внутри производственного помещения [Мурашева и др., 2007, с. 49].

Направление производства и ассортимент продукции. Две ювелирные мастерские Царевского городища, по мнению авторов раскопок, были связаны преемственностью [Федоров-Давыдов и др., 1974, с. 120123]. После затухания жизни на усадьбе, в которой функционировала более ранняя мастерская, мастер со всем инструментарием и сырьем перемещается на территорию другой, соседней усадьбы. На перенос производства может указывать и низкая концентрация в ранней мастерской находок, связанных с производством [Гусева, 1974, с. 132]. Мастер, или мастера, работавшие в этих мастерских, использовали разнообразное сырье, среди которых высокопробное золото [Вайнер, Кринари, 1974, с. 126], серебро, свинец, бронза, драгоценные и полудрагоценные камни. Было зафиксировано использование в качестве сырья вещей, уже бывших в употреблении, а именно стенок бронзовых сосудов, из которых вырезались заготовки для бляшек или накладок. Исходя из находок инструментария (тигли со следами литья, наковаленка, пуансон для нанесения циркульного орнамента), мастера работали как в технике литья, так и обработки давлением. Об ассортименте их продукции можно судить по заготовкам, найденным на территории мастерских. Это накладки и медальоны из бронзы и свинца, перстни со вставками и без, золотые детали поясных наборов [Гусева, 1974, с. 129-130]. Авторами раскопок бы сделан вывод об отсутствии стандартизации в работе этих мастерских и, соответственно, работе скорее на заказ, нежели на свободный рынок [Гусева, 1974, с. 132].

«Мастерская медника» Царевского городища имела более узкую специализацию. В качестве металлического сырья здесь ис- 
пользовались сплавы на основе меди и изготавливались, в том числе, такие бытовые вещи, как бубенчики, муфты для ножей и клепки [Зеленеев, Курочкина, 2009, с. 80]. Из украшений здесь был также обнаружены фрагмент браслета и бронзовая вставка в кольцо. В целом об ассортименте продукции говорить сложно, так как находки разных категорий в основном единичны, и нельзя с точностью определить, что было готовым изделием, а что представляло собой лом, подготовленный для переплавки. Инструментарий представлен фрагментами тиглей и ювелирным молоточком, а в заполнении ям было обнаружено большое количества шлаков цветных металлов и обрезков, так что можно предположить также применение техник литья и обработки давлением.

Единственным атрибутом литейщикаювелира и единственным типом инструментария, обнаруженного в комплексе, открытом на Увекском городище, являются тигли со следами серебра [Кубанкин, 2013, с. 181], металла дорогого и используемого именно в ювелирном деле. Несмотря на то что в сооружении было зафиксировано зольное пятно и в заполнении встречаются фрагменты угольков, наиболее явного свидетельства наличия литейного производства - прослойки с мелкими кусочками угля и каплями металла обнаружено не было. Поэтому говорить, что в данном сооружении проходил узкоспециализированный производственный процесс, следует с некоторой осторожностью.

В мастерских ремесленного квартала к югу и юго-западу от Соборной мечети Болгара работали, прежде всего, со сплавами на основе меди, о чем говорит большая распространенность на данной территории медных шлаков, обрезков металла и изделий, подготовленных для переплавки [Бадеев, Коваль, 2018 , с. 277]. В одной из мастерских, исследованных в этом квартале, кроме медного сырья было встречены серебро в виде проволоки, а также куски свинца, марганца, серы и олова [Кокорина, 2005, с. 113]. О специализации мастеров данного района на литье украшений свидетельствуют находки большого количества форм для изготовления перстней, височных колец, ременных гарнитур, привесок, медальонов, браслетов и т. д. Д.Ю. Бадеевым и В.Ю. Ковалем было подсчитано, что количество форм, происходящих из этого квартала, сопоставимо с общим числом находок на всей территории Болгарского городища [Бадеев, Коваль, 2018, с. 280]. Помимо этого, инструментарий представлен тиглями, пинцетами, мерной ложкой, миниатюрным топориком, молоточком, клещами, ножницами, каменными волочильными досками [Кокорина, 2005, с. 113; Бадеев, Коваль, 2018, с. 281-283]. Мастерские другого ремесленного квартала, расположенного в юго-западной части городища, были ориентированы, прежде всего, на выплавку цветных и черных металлов и на металлообработку меди и медных сплавов, о чем свидетельствуют такие находки, как: куски медного колчедана, медных и железных шлаков, криц, куски и слитки меди, бронзы и свинца, обломки изделий. Готовые изделия представлены в основном обломками, вероятнее всего подготовленными для переплавки. Из инструментов, помимо тиглей и льячек, встречены бронзовая наковальня и железный молоток. Авторами раскопок было сделано предположение, что главной продукцией ремесленников-медников являлась медная посуда [Аксенова, Полубояринова, 2005, с. 135-143].

Мастерская Старого Орхея отличается от рассмотренных выше узкой кузнечной специализацией. Набор инструментов данной мастерской включает напильник, пилу (ножовку), наковальню, стамеску, миниатюрное зубильце, а из готовых изделий встречены проволочные серьги, цепочки, вставки, шаровидные пуговицы, спиралевидные пронизи из тонкой проволоки, тисненая оковка [Бырня, 1974, с. 235-238]. С учетом отсутствия каких-либо следов литья, литейного инструментария (форм и тиглей), а также горна или ямы-очага, где могла происходить плавка металла, можно с достаточной долей уверенности говорить, что мастер занимался исключительно холодной кузнечной обработкой сплавов на основе меди и изготовлением простейших украшений со вставками из стекла, янтаря и жемчуга.

Мастерские, в которых занимались лишь пластической деформацией цветных металлов, открыты также и в древнерусских городах, например в Новгороде [Ениосова и др., 2011, с. 139], однако чаще можно наблюдать, 
что чеканщики и литейщики сосуществовали в одних мастерских. Многие мастерские имели узкую специализацию, например занимались изготовлением медных бубенчиков [Колчин, 1985 , с. 261] или крестиков и книжных застежек, однако крупные производства, как, например, многопрофильная мастерская в детинце Серенска, могли работать и удовлетворять нужды как собственно военного гарнизона, так и изготавливать бытовые изделия и украшения, в том числе из драгоценных металлов [Зайцева, Сарачева, 2011, с. 65, 72].

Сосуществование с другими производствами. Одной из ярких черт мастерских по обработке цветных металлов является их функционирование в составе комплекса производств. Усадебные мастерские Царевского городища формировали комплекс, в который помимо обработки цветного металла входит обработка кости и производство керамики [Гусева, 1974]. На Увекском городище в результате работ 2019 г. открыты следы комплекса производств середины XIV в., где косторезное и кожевенное ремесла соседствуют с обработкой цветных металлов [Яворская, 2020, с. 223]. На Болгарском городище в конце XIII - начале XIV в. к югу и юго-западу от Соборной мечети формируется район, специализирующийся на обработке цветных металлов, но при этом с медниками и ювелирами соседствовали усадьбы, на которых выявлены материалы, связанные с косторезным, стеклоделательным и гончарным производствами. К середине XIV в. здесь возводится и здание базара [Бадеев, Коваль, 2018, с. 277; Кокорина, 2005, с. 114]. В ремесленном квартале в юго-западной части городища обработка цветных металлов сочетается с кузнечным и косторезным ремеслами, гончарным производством [Аксенова, Полубояринова, 2005, c. 145]. На Селитренном городище была исследована усадьба, где помимо основного стеклоделательного производства было зафиксировано косторезное, гончарное производства и обработка полудрагоценных камней [Пигарев, 2020, с. 212]. Можно сделать предположение, что поблизости могло находиться и ювелирное производство, где использовались вставки из стекла и камня, которые производились в этой усадьбе. Таким образом, в основном мастерские по обработке цветных металлов функционируют в комплексе с обработкой кости и изготовлением керамики. Косторезное ремесло, как отмечают большинство исследователей, встречается на территории золотоордынских городов повсеместно и часто выполняет функцию вспомогательного, удовлетворяющего хозяйственные нужды усадьбы и приусадебных мастерских [Аксенова, Полубояринова. 2005, с. 145; Пигарев, 2020 , с. 212]. Гончарное производство в ряде случаев доминирует или полностью сменяет другие ремесленные направления на последних этапах существования производственных комплексов, как, например, в мастерских Царевского городища [Гусева, 1974, с. 133; Кокорина, 2005, с. 116].

В древнерусских городах производства по обработке цветных металлов функционируют в комплексе с косторезным [Ениосова и др., 2011, с. 140; Ениосова, Жарнов, 2006, c. 64], деревообрабатывающим [Рябинин, 1994, с. 53; Сингх, 2011, с. 234-235] и сапожным [Сингх, 2011, с. 233], обработкой камня [Зайцева, Сарачева, 2011, с. 53]. Наиболее часто фиксируется соседство с железоделательным производством [Рябинин, 1994, с. 52; Мурашева и др., 2007; Зайцева, 2010, с. 200; Королева, 2003, с. 223; и др.], причем в таком случае предполагается, что железообрабатывающие производственные помещения использовались и для горячей обработки цветных металлов, в то время как специальные ювелирные горны отсутствуют. Судя по имеющимся на данный момент данным, для золотоордынского ремесла сочетание обработки цветных и черных металлов в целом менее характерно. На Болгарском городище, в районах, где такое сосуществование фиксируется, исследователями отмечается присутствие русского этнического компонента [Аксенова, Полубояринова, 2005, с. 138: Бадеев, 2018, c. 82]. В то же время, по данным этнографии, у кочевых народов мастер по металлу соединял в одном лице и кузнеца, и литейщика, и ювелира, работал с разными материалами и выполнял сам все процессы, от заготовки угля до финальной обработки поверхности изделия, работал в одиночку или привлекая помощника-ученика [Король, Наумова, 2017, с. 57-58].

Многопрофильный характер мастерских может быть связан с вопросами реализации 
продукции, образуя законченный производственный цикл, так как зачастую изготовление одного изделия требует операций разных ремесленных направлений [Рябинин, 1994, с. 54-55]. Кроме того, объединение большого числа ремесел на территории одного комплекса часто говорит о том, что у такого производства должен быть некий внешний организатор, например представитель аристократии или купечества [Сингх, 2011, с. 241; Зайцева, 2010, с. 203-204]. Такая ситуация могла наблюдаться в случае ювелирных мастерских Царевского городища, располагавшихся на территории аристократических усадеб и имевших доступ к драгоценным металлам.

Связь ремесла и купечества демонстрирует мастерская в Старом Орхее, примыкающая одной стеной к караван-сараю, и наиболее ярко - торгово-ремесленный квартал Болгара, где на территории активного функционирования разнообразных ремесленных мастерских возникает и городской базар. Исследователями высказывалось предположение, что за возведением базара, как и в среднеазиатских городах, могли стоять некие ремесленные объединения [Бадеев, Коваль, 2018 , с. 283]. Так, например, в позднесредневековой Бухаре существовали корпорации мастеров по обработке металлов: кузнецов, мастеров по литью чугуна, обработки меди, литью бронзы и ювелиров. У городских ремесленников существовала более узкая специализация внутри корпораций. Ювелиры составляли особую корпорацию касаба, возглавляемую аксакалом, в обязанности которого входило наблюдение за торговлей ювелирными изделиями, качеством работы, ценами на изделия и материалы. При этом корпорация ювелиров была социально раздробленной и объединяла в себе и богатых мастеров, содержащих цеха, и мастеров-одиночек, и наемных мастеров [Сухарева, 1962, с. 53-55]. Ремесленные организации существуют, например, в $\mathrm{Ca}$ марканде уже в предмонгольское время [Зиняков, 2013, с. 232], и можно предположить, что такая организация труда могла быть заимствована золотоордынцами, как и многие другие социальные структуры.

Таким образом, в городах Золотой Орды функционируют разные формы организации металлообрабатывающего ремесла, как не- зависимые небольшие мастерские в ремесленных кварталах, так и комплексные мастерские при усадьбах, которые объединяли несколько видов производств. Вопрос о существовании металлообрабатывающих государственных «цехов» - кархане - остается открытым, но на данный момент уверенно говорить о существовании такой формы организации ремесла все же нельзя.

Расположение металлообрабатывающих мастерских в золотоордынских городах не имеет четко выраженной локализации. Наличие специализированного района по обработке металлов можно осторожно предположить в юго-западной части Болгара. Расположение мастерских подчинялось внутренним потребностям городских кварталов. Усадебные мастерские, отличающиеся некой элитарностью, работали не на рынок, а на заказ, и можно сделать осторожное предположение о том, что они удовлетворяли нужды городской и кочевой аристократии.

Сооружения, в которых функционируют мастерские, не имеют каких-либо конструктивных особенностей и характерны для ремесленных комплексов в целом. В мастерских, специализирующихся на пластической деформации металла, могут отсутствовать теплотехнические сооружения.

Многие золотоордынские мастерские по обработке цветных металлов функционируют в связке с другими ремеслами, наиболее часто фиксируют сочетание с косторезным, гончарным ремеслами, реже - стеклоделательным, кожевенным и обработкой камней. Это достаточно резко отличается от ситуации в древнерусских городах, где комплексы по обработке цветных металлов, помимо других ремесел, чаще сосуществуют с железообрабатывающим производством.

Ремесленные комплексы золотоордынских городов демонстрируют большое разнообразие форм, и большинство из них так или иначе находит аналогии в материалах древнерусских городов. Однако какие-либо значимые специфичные черты, способные указать на возможные генетические связи, выявить на материале организации производственных комплексов довольно затруднительно. Таким образом, решение вопроса влияния русского ремесла на ордынское должно 
лежать, скорее, в сфере изучения применяемых технологий.

\section{ПРИМЕЧАНИЕ}

${ }^{1}$ Исследование выполнено в рамках гранта Министерства науки и высшего образования Российской Федерации по теме «Домонгольские росписи Новгорода: археологический контекст и есте- ственно-научные исследования (фрески Георгиевского собора Юрьева монастыря из раскопок 20132020 годов)», соглашение № 075-15-2021-576.

The research was carried out within the state assignment of Ministry of Science and Higher Education of the Russian Federation (theme "PreMongol frescoes in Novgorod: archaeological context and scientific research: The frescoes of St. Georges Cathedral, Yuriev monastery from the 2013/2020 excavations”), agreement № 075-15-2021-576.

\section{СПИСОК ЛИТЕРАТУРЫ}

Абызова Е. Н., Бырня П. П., Нудельман А. А., 1981. Древности Старого Орхея. Золотоордынский период. Кишинев : Штиинца. 100 с.

Аксенова Н. Д., Полубояринова М. Д., 2005. Исследование ремесленного района юго-западной части Болгарского городища // Древности Поволжья: эпоха средневековья (исследование культурного наследия Волжской Булгарии и Золотой Орды) : материалы II Всерос. конф. «Поволжье в средние века» ( 2528 сентября 2003 г., Казань - Яльчик). Казань : РИЦ «Школа». С. 133-156.

Бадеев Д. Ю., 2018. Ремесленные районы золотоордынского Болгара: попытка локализации // Археология Евразийских степей. № 5. С. 81-86.

Бадеев Д. Ю., Коваль В. Ю., 2018. Исследование ремесленно-торгового района средневекового Болгара // Поволжская археология. № 2 (24). С. 270-289. DOI: https://doi.org/10.24852/pa2018.2.24.270.289.

Байрамова Г. С., Зеленеев Ю. А., 2000. Мастерская медника города Сарай ал-Джедид // Этнокультурные факторы в становлении и развитии металлургии и обработки цветных металлов у народов Поволжья в средние века : тез. Рос. науч. конф. Йошкар-Ола. С. 19-21.

Баллод Ф. В., 1923. Приволжские «Помпеи» : (Опыт художественно-археологического обследования части правобережной Саратовско-Царицынской приволжской полосы). М. : Гос. изд-во ; Пг. : Мосполигpaф. $132 \mathrm{c}$.

Беленицкий А. М., 1948. К вопросу о социальных отношениях в Иране в хулагуидскую эпоху // Советское востоковедение. Т. 5. С. 111-128.

Бырня П. П., 1974. Ювелирная мастерская XIV в. из Старого Орхея // Археологические исследования в Молдавии (1973). Кишинев : Штиинца. С. 229-241.

Вайнер И. С., Кринари Г. А., 1974. Исследование образцов золота из мастерских в районе «Трех усадеб» на Царевском городище (Новый Сарай) // Города Поволжья в средние века. М. : Наука. C. $126-129$.

Валиулина С. И., 2020. Проблема социальной структуры средневекового ремесла Поволжья по археологическим данным // Ученые записки Казанского университета. Серия «Гуманитарные науки». Т. 162, кн. 6. С. 35-46. DOI: https://doi.org/10.26907/2541-7738.2020.6.35-46.

Глухов А. А., 2015. Царевское городище: история изучения, историческая топография, хронология. Волгоград : Волгогр. науч. изд-во. $101 \mathrm{c.}$

Горелик М. В., 2008. Золотоордынские предметы и их местные подражания в материалах древнерусских городов // Краткие сообщения института археологии. Вып. 222. С. 117-125.

Греков Б. Д., Якубовский А. Ю., 1941. Падение Золотой Орды. М. : Госполитиздат. 208 с.

Гусева Т. В., 1974. Ремесленные мастерские в восточном пригороде Нового Сарая // Советская археология. №3. C. $125-141$.

Егоров В. Л., 1970. Жилища Нового Сарая (по материалам исследований 1959-1965 гг.) // Поволжье в средние века. МИА. № 164. М. : Наука. С. 172-193.

Егоров В. Л., 1985. Историческая география Золотой Орды XIII-XIV веков. М. : Наука. 245 с.

Ениосова Н. В., Жарнов Ю. Э., 2006. Ювелирный производственный комплекс из «Ветчаного города» домонгольского Владимира // Российская археология. № 2. С. 64-81. 
Ениосова Н. В., Покровская Л. В., Сингх В. К., Тарабардина О. А., 2011. Ювелирные мастерские Людина конца средневекового Новгорода // Труды III (XIX) Всероссийского археологического съезда. Т. II. СПб. ; М. ; Великий Новгород : ИИМК РАН. С. 139-140.

Зайцева И. Е., 2010. К вопросу об организации ювелирного дела в городах Древней Руси // Славяно-русское ювелирное дело и его истоки : материалы Междунар. науч. конф., посвящ. 100-летию со дня рождения Гали Федоровны Корзухиной (Санкт-Петербург, 10-16 апреля 2006 г.). СПб. : Нестор-История. С. 199-205.

Зайцева И. Е., Сарачева Т. Г., 2011. Ювелирное дело «Земли вятичей» второй половины XI - XIII в. М. : Индрик. 402 с.

Зеленеев Ю. А., Курочкина С. А., 2009. Золотоордынский город Сарай-ал-Джедид (результаты археологических исследований на Царевском городище в 1994-2000 гг.). Йошкар-Ола : Изд-во МарГУ. 264 с.

Зиняков Н. М., 2013. Металлургия и металообработка в средневековых городах Казахстана: характеристика общественных условий и уровня развития производства // Вестник Томского государственного университета. История. № 3 (23). С. 232-234.

Кикнадзе Р. К., 1962. Из истории ремесленного производства (ка̄рха̄нэ) в Иране XIII-XIV вв. // Ближний и средний Восток. М. : Вост. лит. С. 47-55.

Кокорина Н. А., 2005. Ювелирная мастерская из Болгара // Древности Поволжья: эпоха средневековья (исследование культурного наследия Волжской Булгарии и Золотой Орды) : материалы II Всерос. конф. «Поволжье в средние века» (25-28 сентября 2003 г., Казань - Яльчик). Казань : РИЦ «Школа». С. 109-132.

Колчин Б. А., 1985. Ремесло. Обработка цветных металлов // Древняя Русь. Город, замок, село. Археология СССР. Т. 15. М. : Наука. С. 260-265.

Королева Э. В., 2003. Ювелирные ремесленные комплексы Средневекового Пскова // Псков в российской и европейской истории : Междунар. науч. конф. В 2 т. Т. 1. М. : МГУП. С. 219-224.

Король Г. Г., Наумова О. Б., 2017. Вопросы металлобработки у кочевых народов Центральной Азии (раннее средневековье и этнографическое время) // Проблемы истории, филологии и культуры. № 2. С. 52-68.

Крамаровский М. Г., Полубояринова М. Д., 1982. К характеристике городского ювелирного дела Золотой Орды // Советская археология. № 3. С. 96-102.

Кренке Н. А., Ершов И. Н., Муренцева Т. Ю., Хаврин С. В., 2016. Ювелирная мастерская ХІ в. на Рачевке в Смоленске // Краткие сообщения института археологии. № 245 (2). С. 7-28.

Кубанкин Д. А., 2010. Жилище мастера на северо-западной окраине Увекского городища // Археология Нижнего Поволжья: проблемы, поиски, открытия : материалы III Междунар. Нижневолж. археол. конф. (Астрахань, 18-21 октября 2010 г.). Астрахань : Изд. дом «Астраханский университет». С. 220-227.

Кубанкин Д. А., 2013. Археологические раскопки на Увекском городище в 2008-2009 гг. // Археологическое наследие Саратовского края. Вып. 11. Саратов. С. 179-191.

Кулешов Ю. А., 2014. Оборот оружия в Золотой Орде // Золотоордынская цивилизация. № 7. С. 199-251.

Масловский А. Н., 2015. Заметки по топографии золотоордынского города Азака // Генуэзская Газария и Золотая Орда. Кишинев : Stratum Plus. C. 383-410.

Масюта Д. А., Лесная Е. С., 2020. Деталь поясного набора золотоордынского времени из Юго-Западного Крыма // Поволжская археология. № 2. С. 238-247. DOI: https://doi.org/10.24852/pa2020.2.32.238.247.

Мурашева В. В., Ениосова Н. В., Фетисов А. А., 2007. Кузнечно-ювелирная мастерская пойменной части Гнездовского поселения // Гнездово. Результаты комплексных исследований памятника. М. : Альфарет. C. 31-77.

Пигарев Е. М., 2020. Раскопки стеклоделательной мастерской Селитренного городища (итоги работ 20172019 гг.) // Волго-Уральский регион от древности до средневековья : материалы VI Нижневолж. Междунар. археол. конф. Волгоград : Изд-во ВолГУ. С. 210-214.

Полякова Г. Ф., 1996. Изделия из цветных и драгоценных металлов // Город Болгар: ремесло металлургов, кузнецов, литейщиков. Казань : ИЯЛИ АН Татарстана. С. 154-268.

Рашид ад-Дин Ф., 2011. Джами-ат-Таварих. Баку : Нагыл Еви. 540 с.

Рыбаков Б. А., 1948. Ремесло Древней Руси. М. : Изд-во АН СССР. 792 с.

Рындина Н. В., 1963. Технология производства новгородских ювелиров X-XV вв. // Материалы и исследования по археологии СССР. Вып. 117. Новые методы в археологии. Труды Новгородской Археологической Экспедиции. Т. III. М. : ИА АН СССР. С. 200-268. 
Рябинин Е. А., 1994. У истоков ремесленного производства в Ладоге : (К истории общебалтийских связей в предвикингскую эпоху) // Новые источники по археологии Северо-Запада. СПб. : ИИМК РАН. С. 50-59.

Саврасов А. С., 2013. Практика и перспективы экспериментальных исследований металлопроизводства эпохи бронзы Восточноевропейской лесостепи (срубная археологическая общность) // Экспериментальная археология. Взгляд в XXI век : материалы Междунар. полевой науч. конф. Ульяновск : Печатный двор. C. 121-126.

Сафаргалиев М. Г., 1960. Распад Золотой Орды. Саранск : Мордов. кн. изд-во. 276 с.

Сингх В. К., 2011. Производственные комплексы на усадьбах Славенского раскопа // Новгородские археологические чтения - 3 : материалы Междунар. конф. «Археология средневекового города. К 75-летию археологического изучения Новгорода» (Великий Новгород, 25-28 сент. 2007 г.). В. Новгород : Печатный двор. С. 233-242.

Сухарева О. А., 1962. Феодальный город Бухара конца XIX - начала ХХ века. Ремесленная промышленность. Ташкент : Изд-во Акад. наук Узбек. ССР. 365 с.

Терещенко А. В., 1850. Археологические поиски в развалинах Сарая // Записки Санкт-Петербургского археолого-нумизматического общества. Т. ІІ. СПб. С. 364-310.

Троицкий С. О., 2019. Новые данные по ремесленным комплексам по обработке цветных металлов из раскопок городища Старая Рязань // Археология Евразийских степей. № 5. С. 215-220.

Федоров-Давыдов Г. А., 1997. Некоторые итоги изучения городов Золотой Орды на Нижней Волге // Татарская археология. № 1. С. 92-110.

Федоров-Давыдов Г. А., Вайнер И. С., Гусева Т. В., 1974. Исследование трех усадеб в восточном пригороде Нового Сарая (Царевского городища) // Города Поволжья в Средние века. М. : Наука. С. 89-125.

Яворская Л. В., 2020. Ремесленные производства из животного сырья в золотоордынском Укеке: новые данные // Волго-Уральский регион от древности до средневековья : материалы VI Нижневолж. Междунар. археол. науч. конф. Волгоград : Изд-во ВолГУ. С. 222-228.

Якубовский А. Ю., 1931. К вопросу о происхождении ремесленной промышленности Сарая Берке // Известия ГАИМК. Т. 8, вып. 2-3. С. 7-48.

Söderberg A. A., 2002. Metalliska spår efter gjutet iverksamhet- en skiss till en arkeologisk fältmetod // Fornvännen. № 97. S. 255-264.

\section{REFERENCES}

Abyzova E.N., Byrnya P.P., Nudel'man A.A., 1981. Drevnosti Starogo Orheya. Zolotoordynskiy period [Antiquities of the Staryy Orhey. The Golden Horde Period]. Kishinev, Shtiintsa Publ. 100 p.

Aksenova N.D., Poluboyarinova M.D., 2005. Issledovanie remeslennogo rayona yugo-zapadnoy chasti Bolgarskogo gorodishcha [Exploration of the Handicraft Area of the Southwestern Part of the Bolgarskoe Settlement]. Drevnosti Povolzh'ya: epoha srednevekov'ya (issledovanie kul'turnogo naslediya Volzhskoy Bulgarii $i$ Zolotoy Ordy): materialy II Vserossiyskoy konfenrentsii «Povolzh'e v srednie veka», 25-28 sentyabrya 2003 g., Kazan'-Yal'chik [Antiquities of the Volga Region: the Middle Ages (Study of the Cultural Heritage of the Volga Bulgaria and the Golden Horde). Materials of the II All-Russian Conference "The Volga Region in the Middle Ages", September 25-28, 2003, Kazan-Yalchik]. Kazan', Shkola Publ., pp. 133-156.

Badeev D.Yu., 2018. Remeslennye rayony zolotoordynskogo Bolgara: popytka lokalizatsii [Craft Areas of the Golden Horde Bolgar: an Attempt at Localization]. Arheologiya Evraziyskih stepey [Archaeology of the Eurasian Steppes], no. 5, pp. 81-86.

Badeev D.Yu., Koval' V.Yu., 2018. Issledovanie remeslenno-torgovogo rayona srednevekovogo Bolgara [Studies of the Trade and Craft District of Medieval Bolgar]. Povolzhskaya arheologiya [The Volga River Region Archaeology], no. 2 (24), pp. 270-289. DOI: https://doi.org/10.24852/pa2018.2.24.270.289.

Bayramova G.S., Zeleneev Yu.A., 2000. Masterskaya mednika goroda Saray al-Dzhedid [Workshop of the Coppersmith of the City of Saray al-Jedid]. Etnokul turnye faktory $v$ stanovlenii i razvitii metallurgii i obrabotki tsvetnyh metallov u narodov Povolzh'ya v srednie veka: tezisy Rossiyskoy nauchnoy konferentsii [Ethnocultural Factors in the Formation and Development of Metallurgy and Processing of Non-Ferrous Metals Among the Peoples of the Volga Region in the Middle Ages. Abstracts of the Russian Scientific Conference]. Yoshkar-Ola, pp. 19-21. 
Ballod F.V., 1923. Privolzhskie «Pompei»: (Opyt hudozhestvenno-arheologicheskogo obsledovaniya chasti pravoberezhnoy Saratovsko-Tsaritsynskoy privolzhskoy polosy) [Volga "Pompeii": (Experience of Artistic and Archaeological Survey of Part of the Right-Bank Saratov-Tsaritsyn Volga Strip)]. Moscow, Mospoligraf Publ.; Petrograd, Gosudarstvennoe izdatel'stvo Publ. 132 p.

Belenitskiy A.M., 1948. K voprosu o sotsial'nyh otnosheniyah v Irane v hulaguidskuyu epohu [On the Issue of Social Relations in Iran in the Hulaguid Era]. Sovetskoe vostokovedenie [Soviet Oriental Studies], vol. 5, pp. 111-128.

Byrnya P.P., 1974. Yuvelirnaya masterskaya XIV v. iz Starogo Orheya [Jewelry Workshop of the XIV Century from Old Orhey]. Arheologicheskie issledovaniya v Moldavii (1973) [Archaeological Research in Moldova (1973)]. Kishinev, Shtiintsa Publ., pp. 229-241.

Vayner I.S., Krinari G.A., 1974. Issledovanie obraztsov zolota iz masterskih v rayone «Trekh usadeb» na Tsarevskom gorodishche (Novyy Saray) [Study of Gold Samples from Workshops in the Area of "Three Estates" on the Tsarevskoye Settlement (Novyy Saray)]. Goroda Povolzh'ya v srednie veka [Volga Cities at Middle Ages]. Moscow, Nauka Publ., pp. 126-129.

Valiulina S.I., 2020. Problema sotsial'noy struktury srednevekovogo remesla Povolzh'ya po arheologicheskim dannym [The Social Structure of Medieval Craft in the Volga Region Based on Archaeological Data]. Uchenye zapiski Kazanskogo universiteta. Seriya "Gumanitarnye nauki» [Scientific notes of Kazan University. Series Humanities], vol. 162, no. 6, pp. 35-46. DOI: https://doi.org/10.26907/2541-7738.2020.6.35-46.

Gluhov A.A., 2015. Tsarevskoe gorodishche: istoriya izucheniya, istoricheskaya topografiya, hronologiya [Tsarevskoe Settlement: History of Study, Historical Topography, Chronology]. Volgograd, Volgogradskoe nauchnoe izdatel'stvo Publ. $101 \mathrm{p}$.

Gorelik M.V., 2008. Zolotoordynskie predmety i ih mestnye podrazhaniya v materialah drevnerusskih gorodov [Golden Horde Objects and Their Local Imitations in the Materials of Ancient Russian Cities]. Kratkie soobshcheniya instituta arheologii [Brief Communications of the Institute of Archaeology], iss. 222, pp. 117-125.

Grekov B.D., Yakubovskiy A.Yu., 1941. Padenie Zolotoy Ordy [Fall of the Golden Horde]. Moscow, OGIZ Gospolitizdat Publ. 208 p.

Guseva T.V., 1974. Remeslennye masterskie v vostochnom prigorode Novogo Saraya [Craft Workshops in the Eastern Suburbs of Novyy Saray]. Sovetskaya arheologiya [Soviet Archaeology], no. 3, pp. 125-141.

Egorov V.L., 1970. Zhilishcha Novogo Saraya (po materialam issledovaniy 1959-1965 gg.) [Dwellings of the New Saray (Based on Research Materials 1959-1965)]. Povolzh'e v srednie veka [The Volga Region at Middle Ages]. Materialy i Issledovaniya po Arkheologii, no. 164. Moscow, Nauka Publ., pp. 172-193.

Egorov V.L., 1985. Istoricheskaya geografiya Zolotoy Ordy XIII-XIVvekov [Historical Geography of the Golden Horde at XIII-XIV Centuries]. Moscow, Nauka Publ. 245 p.

Eniosova N.V., Zharnov Yu.E., 2006. Yuvelirnyy proizvodstvennyy kompleks iz «Vetchanogo goroda» domongol'skogo Vladimira [Jewellery Production Association from "Vetchany Gorod" of Pre-Mongol Vladimir]. Rossiyskaya arheologiya [Russian Archaeology], no. 2, pp. 64-81.

Eniosova N.V., Pokrovskaya L.V., Singh V.K., Tarabardina O.A., 2011. Yuvelirnye masterskie Lyudina kontsa srednevekovogo Novgoroda [Jewelry Workshops of the Ludin Ends at the Medieval Novgorod]. Trudy III (XIX) Vserossiyskogo arheologicheskogo syezda [Proceedings of III (XIX) All-Russian Archaeological Congress], vol. II. St. Petersburg, Moscow, Veliky Novgorod, IHMC RAS, pp. 139-140.

Zaytseva I.E., 2010. K voprosu ob organizatsii yuvelirnogo dela v gorodah Drevney Rusi [On the Problem of Organization of Jewellers Handicraft in Ancient Russian Towns]. Slavyano-russkoe yuvelirnoe delo i ego istoki: materialy Mezhdunarodnoy nauchnoy konferentsii, posvyashchennoy 100-letiyu so dnya rozhdeniya Gali Fyodorovny Korzuhinoy. Sankt-Peterburg, 10-16 aprelya 2006 [Slavic and Old Russian Art of Jewelry and its Roots. Materials of the International Scientific Conference Dedicated to the $100^{\text {th }}$ Anniversary of Gali Korzukhinas Birth. St. Petersburg, 10-16 April 2006]. St. Petersburg, Nestor-Istoriya Publ., pp. 199-205.

Zaytseva I.E., Saracheva T.G., 2011. Yuvelirnoe delo «Zemli vyatichey» vtoroy poloviny XI-XIII v. [Jewellers Craft of the "Land of Vyatichi" in the Second Half of the $11^{\text {th }}-13^{\text {th }}$ Centuries]. Moscow, Indrik Publ. $402 \mathrm{p}$.

Zeleneev Yu.A., Kurochkina S.A., 2009. Zolotoordynskiy gorod Saray-al-Dzhedid (rezul'taty arheologicheskih issledovaniy na Tsarevskom gorodishche v 1994-2000 gg.) [The Golden Horde City of Saray-al-Jedid (Results of Archaeological Research at the Tsarevskoye Settlement in 1994-2000)]. Yoshkar-Ola, MarSU. 264 p.

Zinyakov N.M., 2013. Metallurgiya i metaloobrabotka v srednevekovyh gorodah Kazahstana: harakteristika obshchestvennyh usloviy i urovnya razvitiya proizvodstva [Metallurgy and Metalworking in Medieval 
Cities of Kazakhstan: Characteristics of Social Conditions and the Level of Production Development]. Vestnik Tomskogo gosudarstvennogo universiteta. Istoriya [Tomsk State University Journal of History], no. 3 (23), pp. 232-234.

Kiknadze R.K., 1962. Iz istorii remeslennogo proizvodstva (kārhāne) v Irane XIII-XIV vv. [From the History of Handicraft Production (karkhane) in Iran XIII-XIV Centuries]. Blizhniy i sredniy Vostok [Near and Middle East]. Moscow, Vostochnaya literatura Publ., pp. 47-55.

Kokorina N.A., 2005. Yuvelirnaya masterskaya iz Bolgara [Jewelry Workshop at Bolgar]. Drevnosti Povolzh'ya : epoha srednevekov'ya (issledovanie kul 'turnogo naslediya Volzhskoy Bulgarii i Zolotoy Ordy): materialy II Vserossiyskoy konfenrentsii «Povolzh'e v srednie veka», 25-28 sentyabrya 2003 g., Kazan'-Yal'chik [Antiquities of the Volga Region: the Middle Ages (Study of the Cultural Heritage of the Volga Bulgaria and the Golden Horde). Materials of the II All-Russian Conference "The Volga Region in the Middle Ages" September 25-28, 2003, Kazan-Yalchik]. Kazan, Shkola Publ., pp. 109-132.

Kolchin B.A., 1985. Remeslo. Obrabotka tsvetnyh metallov [Craft. Processing of non-ferrous metals]. Drevnyaya Rus'. Gorod, zamok, selo [Ancient Rus. Town, Castle, Village]. Arheologiya SSSR, vol. 15. Moscow, Nauka Publ., pp. 260-265.

Koroleva E.V., 2003. Yuvelirnye remeslennye kompleksy Srednevekovogo Pskova [Jewelry Craft Complexes of Medieval Pskov]. Pskov v rossiyskoy i evropeyskoy istorii: Mezhdunarodnaya nauchnaya konferentsiya [Pskov in Russian and European History: International Scientific Conference], vol. 1. Moscow, MSUPA, pp. 219-224.

Korol' G.G., Naumova O.B., 2017. Voprosy metallobrabotki u kochevyh narodov Tsentral'noy Azii (rannee srednevekov'e i etnograficheskoe vremya) [Issues of Metalworking of the Nomadic Peoples of Central Asia (Early Middle Ages and Ethnographic Time)]. Problemy istorii, filologii i kul 'tury [Issues of History, Philology and Culture], no. 2, pp. 52-68.

Kramarovskiy M.G., Poluboyarinova M.D., 1982. K harakteristike gorodskogo yuvelirnogo dela Zolotoy Ordy [The Jewellers Art in the Golden Horde Towns]. Sovetskaya arheologiya [Soviet Archaeology], no. 3, pp. 96-102.

Krenke N.A., Ershov I.N., Murentseva T.Yu., Havrin S.V., 2016. Yuvelirnaya masterskaya XI v. na Rachevke v Smolenske [Jewelry Workshop at Rachevka in Smolensk]. Kratkie soobshcheniya instituta arheologii [Brief Communications of the Institute of Archaeology], no. 245 (2), pp. 7-28.

Kubankin D.A., 2010. Zhilishche mastera na severo-zapadnoy okraine Uvekskogo gorodishcha [A Master's Dwelling on the North-Western Outskirts of the Uvek Settlement]. Arheologiya Nizhnego Povolzh'ya: problemy, poiski, otkrytiya: materialy III Mezhdunarodnoy Nizhnevolzhskoy arheologicheskoy konferentsii (Astrahan', 18-21 oktyabrya 2010 g.) [Archeology of the Lower Volga Region: Problems, Searches, Discoveries. Materials of the III International Lower Volga Archaeological Conference (Astrakhan, October 18-21, 2010)]. Astrahan', Izdatel'skiy dom “Astrahanskiy universitet” Publ., pp. 220-227.

Kubankin D.A., 2013. Arheologicheskie raskopki na Uvekskom gorodishche v 2008-2009 gg. [Archaeological Excavations at the Uvek Settlement in 2008-2009]. Arheologicheskoe nasledie Saratovskogo kraya [Archaeological Heritage of the Saratov Region], iss. 11. Saratov, pp. 179-191.

Kuleshov Yu. A., 2014. Oborot oruzhiya v Zolotoy Orde [Trafficking of Arms in the Golden Horde]. Zolotoordynskaya tsivilizatsiya [Golden Horde Civilization], no. 7, pp. 199-251.

Maslovskiy A.N., 2015. Zametki po topografii zolotoordynskogo goroda Azaka [Notes on the Topography of the Golden Horde Town of Azak]. Genuezskaya Gazariya i Zolotaya Orda [The Genoese Gazaria and the Golden Horde]. Kishinev, Stratum Plus Publ., pp. 383-410.

Masyuta D.A., Lesnaya E.S., 2020. Detal' poyasnogo nabora zolotoordynskogo vremeni iz Yugo-Zapadnogo Kryma [Detail of a Belt Set from the Golden Horde Period from South-Western Crimea]. Povolzhskaya arheologiya [The Volga River Region Archaeology], no. 2, pp. 238-247. DOI: https://doi.org/10.24852/pa2020.2.32.238.247.

Murasheva V.V., Eniosova N.V., Fetisov A.A., 2007. Kuznechno-yuvelirnaya masterskaya poymennoy chasti Gnezdovskogo poseleniya [Forging and Jewelry Workshop of the Floodplain Part of the Gnezdovo Settlement]. Gnezdovo. Rezul taty kompleksnyh issledovaniy pamyatnika [Gnezdovo. The Results of Comprehensive Studies of the Monument]. Moscow, Al'faret Publ., pp. 31-77.

Pigarev E.M., 2020. Raskopki steklodelatel'noy masterskoy Selitrennogo gorodishcha (itogi rabot 2017-2019 gg.) [Excavations of the Glass-Making workshop of the selitrennoe settlement (results of work 2017-2019)]. Volgo-Ural'skiy region ot drevnosti do srednevekov'ya: materialy VI Nizhnevolzhskoy Mezhdunarodnoy arheologicheskoy konferentsii [The Volga-Ural Region From the Ancient to the Medieval Time. Proceedings of the VI Lower Volga International Archaeological Conference]. Volgograd, VolSU, pp. 210-214. 
Polyakova G.F., 1996. Izdeliya iz tsvetnyh i dragotsennyh metallov [Non-ferrous and Precious Metal Items]. Gorod Bolgar: remeslo metallurgov, kuznetsov, liteyshchikov [City of Bolgar: Craft of Metallurgists, Blacksmiths, Casters]. Kazan', IYALI AN Tatarstana, pp. 154-268.

Rashid ad-Din F., 2011. Dzhami-at-Tavarih. Baku, Nagyl Evi Publ. 540 p.

Rybakov B. A., 1948. Remeslo Drevney Rusi [The Craft of Ancient Rus ]. Moscow, AS USSR. 792 p.

Ryndina N.V., 1963. Tekhnologiya proizvodstva novgorodskih yuvelirov X-XV vv. [Production Technology of Novgorod Jewelers of the X-XV Centuries]. Novye metody v arheologii. Trudy Novgorodskoy Arheologicheskoy Ekspeditsii [New Methods in Archaeology. Proceedings of the Novgorod Archaeological Expedition], vol. III. Materialy i issledovaniya po arheologii SSSR, iss. 117. Moscow, IAAS USSR, pp. 200-268.

Ryabinin E.A., 1994. U istokov remeslennogo proizvodstva v Ladoge: (K istorii obshchebaltiyskih svyazey v predvikingskuyu epohu) [At the Origins of Handicraft Production in Ladoga: (On the History of General Baltic Relations in the Pre-Viking Era)]. Novye istochniki po arheologii Severo-Zapada [New Sources on Archaeology of the Northwest]. St. Petersburg, IHMC RAS, pp. 50-59.

Savrasov A.S., 2013. Praktika i perspektivy eksperimental'nyh issledovaniy metalloproizvodstva epohi bronzy Vostochnoevropeyskoy lesostepi (srubnaya arheologicheskaya obshchnost') [Practice and Prospects of Experimental Research of Metal Production of the Bronze Age of the East European Forest-Steppe (Srubnaya Archaeological Community)]. Eksperimental'naya arheologiya. Vzglyad $v$ XXI vek: materialy Mezhdunarodnoy polevoy nauchnoy konferentsii [Experimental Archaeology. A Look into the XXI Century. Materials of the International Field Scientific Conference]. Ul'yanovsk, Pechatnyy dvor Publ., pp. 121-126.

Safargaliev M.G., 1960. Raspad Zolotoy Ordy [The Decay of the Golden Horde]. Saransk, Mordovskoe knizhnoe izdatel'stvo Publ. 276 p.

Singh V.K., 2011. Proizvodstvennye kompleksy na usad'bah Slavenskogo raskopa [Production Complexes on the Estates of the Slavensky Excavation]. Novgorodskie arheologicheskie chteniya - 3: materialy Mezhdunar. konf. «Arheologiya srednevekovogo goroda. K 75-letiju arheologicheskogo izuchenija Novgoroda» (Velikiy Novgorod, 25-28 sent. 2007 g.) [Novgorod Archaeological Readings - 3. Materials of the All-Russian Conference "Archaeology of a Medieval City. To the $75^{\text {th }}$ Anniversary of the Archaeological Study of Novgorod" (Veliky Novgorod, September 25-28, 2007)]. Veliky Novgorod, Pechatnyy dvor Publ., pp. 233-242.

Suhareva O.A., 1962. Feodal'nyy gorod Buhara kontsa XIX-nachala XX veka. Remeslennaya promyshlennost'[Feudal City of Bukhara of the Late $19^{\text {th }}-$ Early $20^{\text {th }}$ Centuries. Handicraft Industry]. Tashkent, AS Uzbek SSR. 365 p.

Tereshchenko A.V., 1850. Arheologicheskie poiski v razvalinah Saraya [Archaeological Searches in the Ruins of the Saray]. Zapiski Sankt-Peterburgskogo arheologo-numizmaticheskogo obshchestva [Notes of the St. Petersburg Archaeological and Numismatic Society], vol. II. St. Petersburg, pp. 364-310.

Troitskiy S.O., 2019. Novye dannye po remeslennym kompleksam po obrabotke tsvetnyh metallov iz raskopok gorodishcha Staraya Ryazan' [New Information on the Craft Complexes Related to the Processing of Ferrous Metals from the Excavations of Staraya Ryazan Settlement]. Arheologiya Evraziyskih stepey [Archaeology of the Eurasian Steppes], no. 5, pp. 215-220.

Fedorov-Davydov G. A., 1997. Nekotorye itogi izucheniya gorodov Zolotoy Ordy na Nizhney Volge [Some Results of the Study of the Cities of the Golden Horde on the Lower Volga]. Tatarskaya arheologiya [Tatar Archaeology], no. 1, pp. 92-110.

Fedorov-Davydov G.A., Vayner I.S., Guseva T.V., 1974. Issledovanie trekh usadeb v vostochnom prigorode Novogo Saraya (Tsarevskogo gorodishcha) [Study of Three Estates in the Eastern Suburb of New Saray (Tsarevskoe Settlement)]. Goroda Povolzh'ya v Srednie veka [Volga Cities at MiddleAges]. Moscow, Nauka Publ., pp. 89-125.

Yavorskaya L.V., 2020. Remeslennye proizvodstva iz zhivotnogo syr'ya v zolotoordynskom Ukeke: novye dannye [Craft Products from Animal Raw Materials in Golden Horde City Ukek: New Data]. Volgo-Ural'skiy region ot drevnosti do srednevekov'ya: materialy VI Nizhnevolzhskoy Mezhdunarodnoy arheologicheskoy nauchnoy konferentsii [The Volga-Ural Region From the Ancient to the Medieval Time. Proceedings of the VI Lower Volga International Archaeological Conference]. Volgograd, VolSU, pp. 222-228.

Yakubovskiy A.Yu., 1931. K voprosu o proiskhozhdenii remeslennoy promyshlennosti Saraya Berke [On the Origin of the Craft Industry of Saray Berke]. Izvestiya GAIMK [Reports of the State Academy of the History of Material Culture], vol. 8, iss. 2-3, pp. 7-48.

Söderberg A.A., 2002. Metalliska spår efter gjutet iverksamhet- en skiss till en arkeologisk fältmetod. Fornvännen, no. 97, pp. 255-264. 
K.S. Kovaleva. Manufacturing Complexes for the Non-Ferrous Metals Processing of the Golden Horde Cities

\section{Information About the Author}

Kseniya S. Kovaleva, Researcher, Laboratory for Architectural Archaeology and Interdisciplinary Studies of Monuments of Architecture, Institute of Archaeology of the Russian Academy of Sciences, Dm. Ulyanova St, 19, 117036 Moscow, Russian Federation; Laboratory Assistant, Laboratory for Archaeological Research, Volgograd State University, Prosp. Universitetsky, 100, 400062 Volgograd, Russian Federation, ksenmorgan@gmail.com, kovaleva@volsu.ru, https://orcid.org/0000-0002-5429-1072

\section{Информация об авторе}

Ксения Сергеевна Ковалева, научный сотрудник лаборатории архитектурной археологии и междисциплинарного изучения архитектурных памятников, Институт археологии РАН, ул. Дм. Ульянова, 19, 117036 г. Москва, Российская Федерация; лаборант лаборатории археологических исследований, Волгоградский государственный университет, просп. Университетский, 100, 400062, г. Волгоград, Российская Федерация, ksenmorgan@gmail.com, kovaleva@volsu.ru, https://orcid.org/0000-0002-5429-1072 